\title{
The North Atlantic Provenance Database: an introduction
}

\author{
Christian Knudsen ${ }^{* 1}$, Martin Sønderholm¹, Tjerk Heijboer ${ }^{1}$, Jeppe Ågård Kristensen² and Dag Bering ${ }^{3}$
}

RESEARCH ARTICLE | OPEN ACCESS

GEUS Bulletin Vol 43 | e2019430301 | Published online: 22 July 2019

https://doi.org/10.34194/GEUSB-201943-03-01

The amount of provenance information available for onshore and offshore sedimentary deposits in the North Atlantic Region is substantial and rapidly increasing. These data provide an improved understanding of reservoir geology (quality, diagenetic issues, regional source-to-sink relations and local stratigraphic correlations), and thereby can reduce hydrocarbon exploration risk.

As such, the number of proprietary, industry-related and public research provenance studies has increased considerably in recent years, and the development and use of new analytical techniques has also caused a surge in the number of grains, isotopes and chemical elements analysed in each study. As a result, it is today close to impossible for the individual researcher or petroleum geologist to draw on all existing provenance data. And the vast expansion of data availability demands new and better methods to analyse and visualise large amounts of data in a systematic way.

To this end, the Geological Survey of Denmark and Greenland (GEUS) and the Norwegian Petroleum Directo- rate (NPD) have established a web-based database of provenance data for the North Atlantic area: the North Atlantic Provenance Database. Construction of the database was funded jointly by GEUS and NPD. Future maintenance and further development will be funded by the petroleum industry by subscription to the database.

The database was launched in March 2019 and can be accessed at https://data.geus.dk/provenance. Access to the database is granted via application to the steering committee, comprised of staff at GEUS, NPD and sponsoring petroleum companies. The aims of the database are three-fold:

- Assemble provenance data from onshore and offshore Greenland, Faroe Islands, Norway and neighbouring areas.

- Make the data easily assessable to the petroleum industry and research institutions for visualisation and statistical analysis through a web application.

- Facilitate research as well as development of new provenance tools and techniques that can reduce exploration risk.

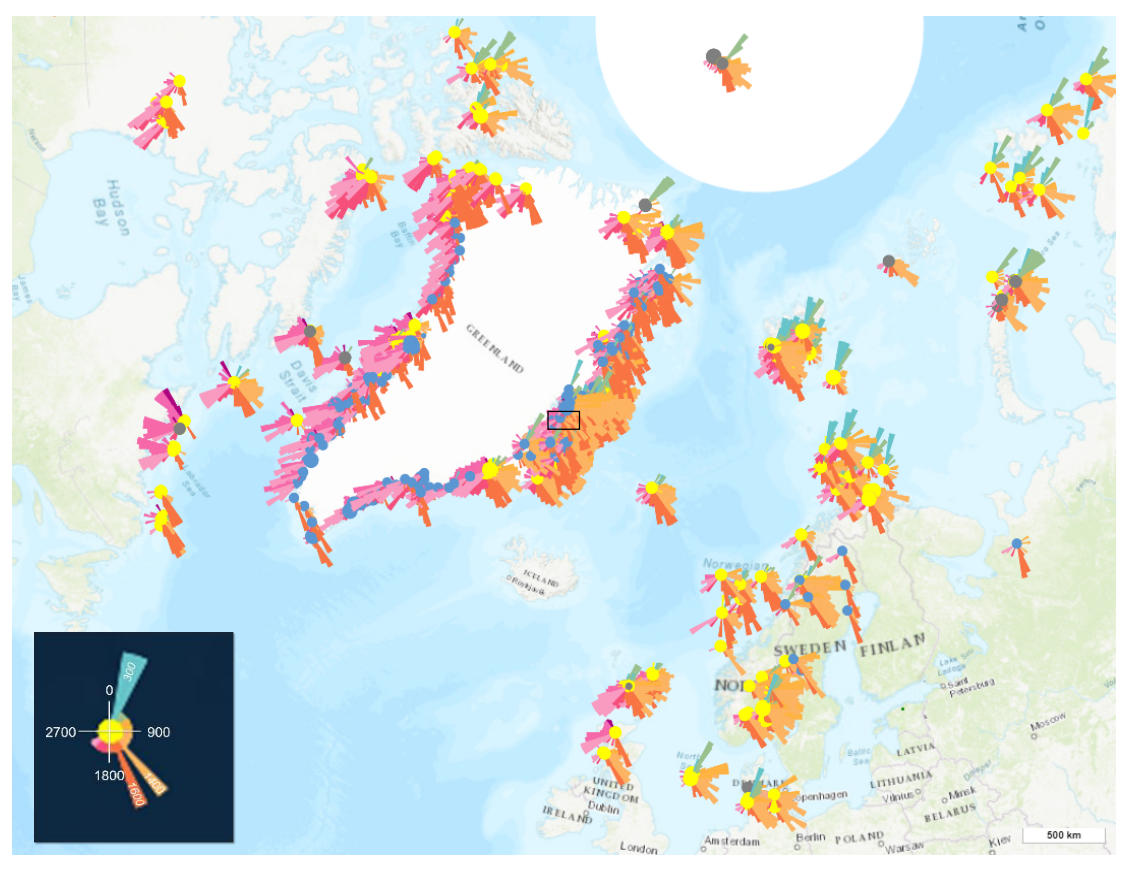

Fig. 1. Output map from the database showing the detrital zircon age distributions available as of July 2019. Each data point (sample) is marked by either a yellow or a blue dot representing a sandstone sample or a present-day drainage sample, respectively. The rosette visualises the age distribution histogram where 'North' is 0 $\mathrm{Ma}$ and 'South' is $1.8 \mathrm{Ga}$ with clockwise increasing ages. The length of each bar represents the frequency in $100 \mathrm{Ma}$ bins. Inset: area shown in Fig. 2. 


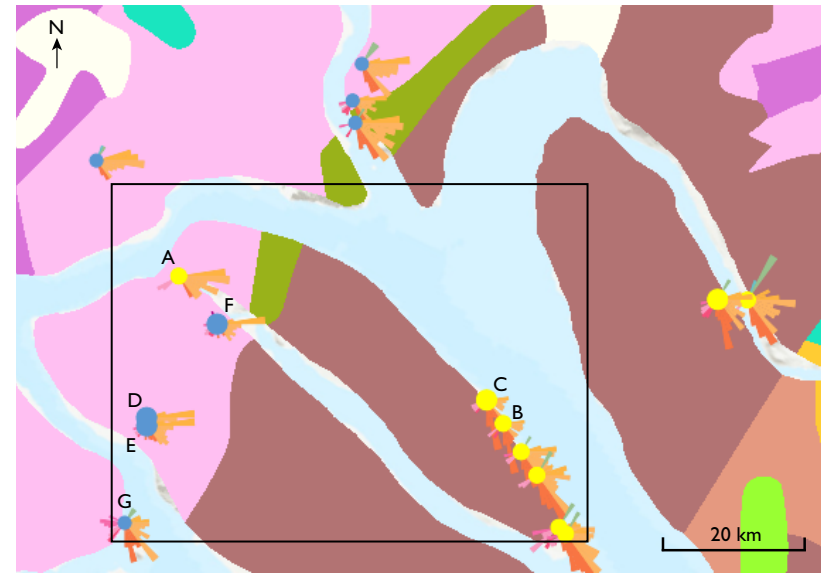

Fig. 2. Geological map (1:500 000) of Ymer Ø in the Kong Oscar Fjord area, East Greenland (output directly from the database; location marked in Fig.1). Locations of stream sediment (blue) and sandstone samples (yellow) are marked, see Fig. 1 for further details. Inset: sampling locations of the seven samples (A-G; see Fig. 3) discussed in the text.

Here, we provide a brief introduction to the database and its future development and expansion. We highlight the current capabilities with an example from East Greenland.

\section{Database contents, development and application}

The North Atlantic Provenance Database is a spatiotemporal, object-rational database in PostgreSQL. It consists of two main packages:

- A database for storage of:

- Detrital zircon age data and other types of provenance data

- Metadata with information about the samples and the analytical procedure used

- An analytical module allowing users to compile, compare and analyse the datasets.

\section{Data}

At the time of publication (July 2019), the database consists of 1659 sandstone samples and 413 stream sediment samples, each containing detrital zircon $\mathrm{U}-\mathrm{Pb}$ ages, together with metadata such as coordinates, stratigraphic data, analytical data and a reference to where the data are published. The database contains more than 170000 detrital zircon U-Pb ages.

The detrital zircon $\mathrm{U}-\mathrm{Pb}$ age data available in the database (July 2019) are summarised in Fig.1. At present, detrital zircon $\mathrm{U}-\mathrm{Pb}$ age data constitute by far the main part of the existing provenance data in the North Atlantic Provenance Database. Other provenance data types, such as detrital

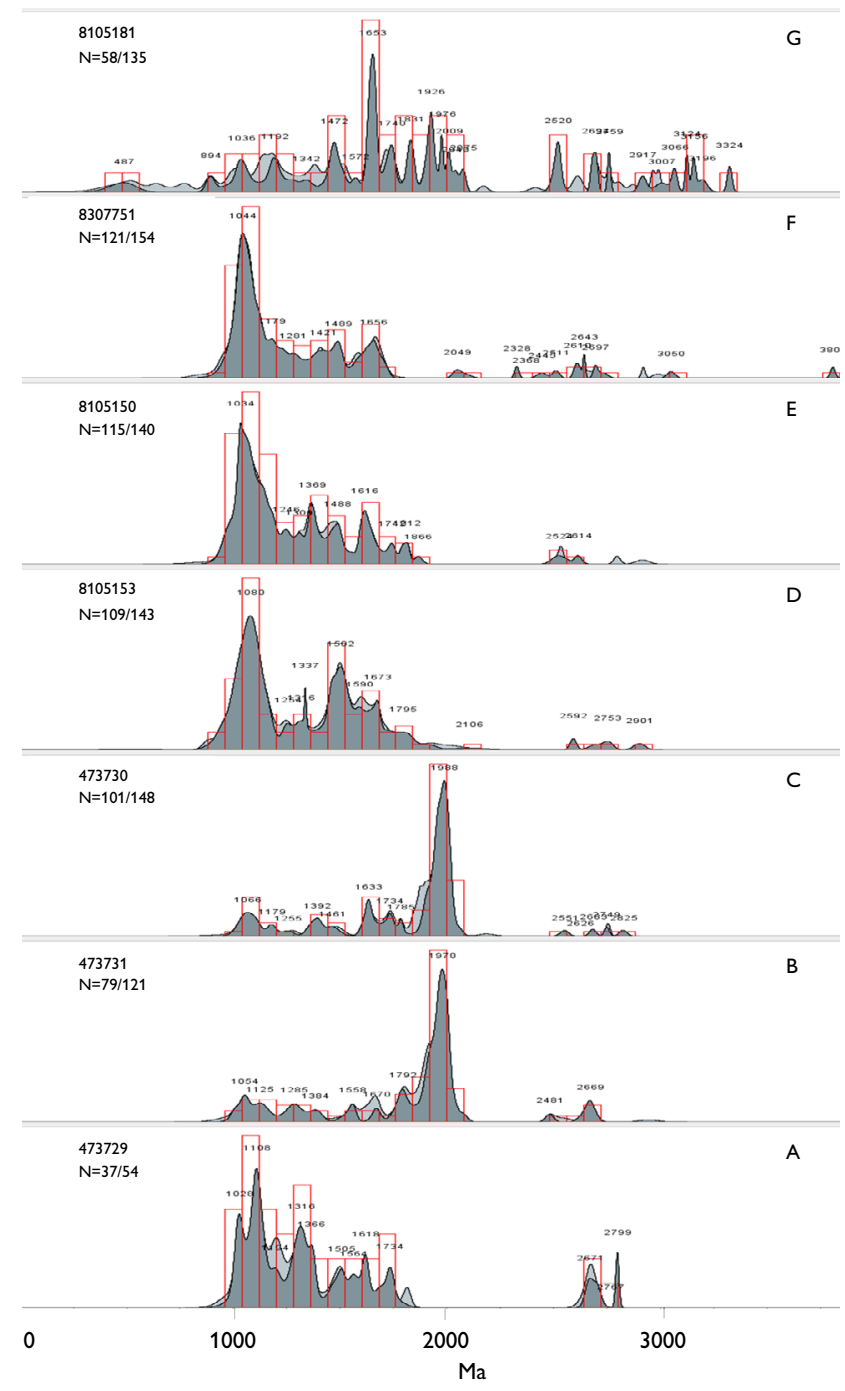

Fig. 3. Detrital zircon age distribution histograms of the seven samples (A-G) selected in Fig. 2. (Rehnström et al. 2010). The histograms are generated according to Thomsen $e t$ al. (2016).

rutile, monazite and apatite $\mathrm{U}-\mathrm{Pb}$ age data as well as stable heavy mineral distributions and heavy mineral chemistry, will be included at later stages. The analytical capabilities and possibilities are under constant change and the database structure is therefore flexible, to accommodate parameters that are not yet part of standard provenance analysis.

Most of the data from Greenland that are stored in the database are comprised of onshore outcrop samples, but also include shallow core wells and samples from present-day drainage systems. In eastern Greenland, $c .500$ samples have been analysed for provenance properties. Of these, more than 400 were analysed by GEUS. The database contains the age distribution of these detrital zircon grains as well as their heavy mineral distribution and compositions. In addition, the database also contains results from various studies 
in East Greenland: some are published (e.g. Røhr et al. 2008; Kirkland et al. 2009; Sláma et al. 2011; Olivarius et al. 2018), and others are to be found in unpublished theses and company reports.

A wealth of offshore and onshore data is available for Norway. Some data have been extracted from published work, but the vast majority of the data are yet to be recovered from either unpublished academic work or company reports. On the Norwegian shelf, a large number of samples have been analysed for their detrital zircon age distribution and heavy mineral content. Again, some of these data are published (e.g. Morton et al. 2005; Lorenz et al. 2013; Fleming et al. 2016) and others are yet to be extracted from unpublished theses and company reports.

Data from neighbouring territories such as West Greenland, Arctic Russia and Canada, the Faroe Islands, Denmark and the UK are also accessible in the database.

\section{Analytical Module}

Users can query the database via the analytical module interface, where they can view and analyse the relevant datasets for a given number of samples. From here, users can generate various visualisations of the data and export them as figures in PDF format. Note that the data belong to the institutions that produced them and so they are not directly available to download from the database. However, the database contains full bibliographic information and links to where the data can be found.

A more detailed description of the database architecture will be published alongside the database at a later date. Here, we simply demonstrate some of functionality, using seven samples from Gunner Andersen Land, Ymer $\varnothing$ in Kong Oscar Fjord, East Greenland (Rehnström et al. 2010; location in Fig. 2). Stream sediment samples from present-day drainage systems and Proterozoic and Devonian sandstones were chosen for further analysis. Visual inspection of the detrital zircon age distribution rosettes (Fig. 2) and histograms (Fig. 3) show distinct modal variation between the seven samples.
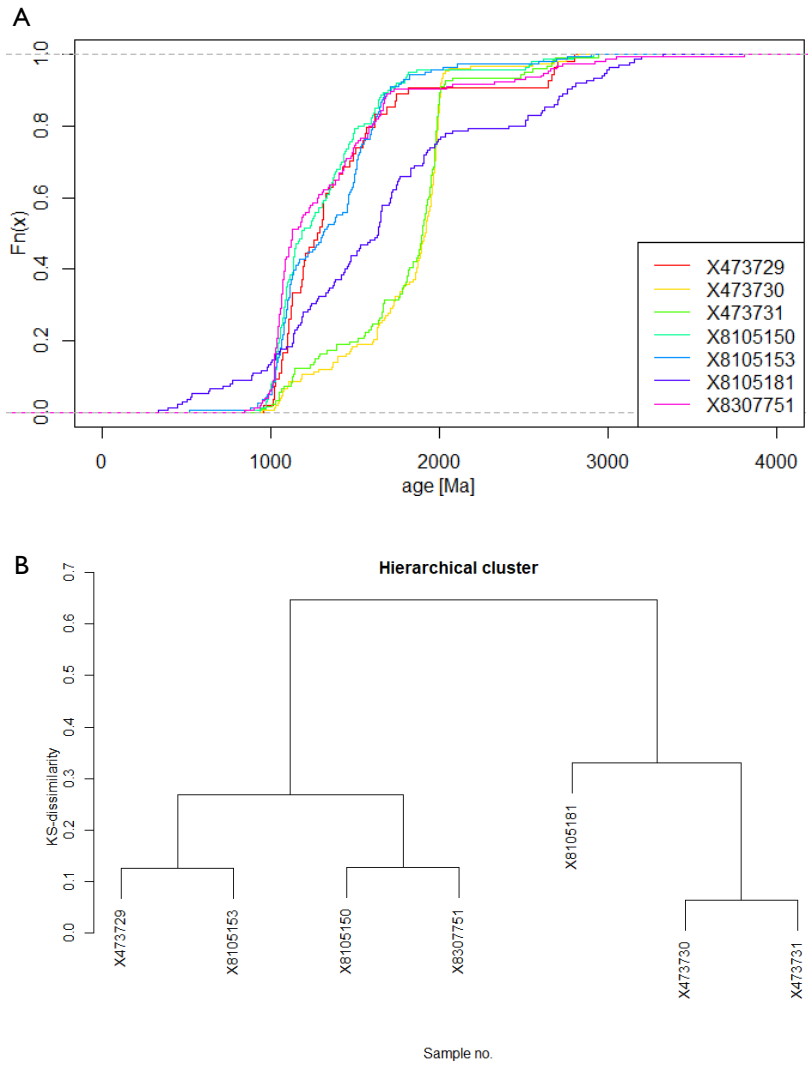

Fig. 4. Kolmogorov-Smirnov (KS) dissimilarities of the seven selected samples. A: Cumulative age distributions. B: Hierarchical clustering.

This is confirmed by the Kolmogorov-Smirnov (KS) dissimilarity test (Fig. 4 and Table 1). Some of the metadata available in the database for these samples are shown in Table 2.

Sample 473729 (Fig. 3A) represents the Sandertop Formation of the Upper Proterozoic Lyell Land Group, part of the Eleonore Bay Supergroup. Detrital zircon ages span the Palaeoproterozoic-Mesoproterozoic eras, with a few Archaean grains. Samples 473730 (Fig 3C) and 473731 (Fig. 3B) represent the Devonian Kap Kolthoff Group consisting of immature sandstone and conglomerate. The detrital zircon age distributions are dominated by a Palaeoproterozoic

Table 1. Kolmogorov-Smirnov (KS) dissimilarity matrix of the seven selected samples.

\begin{tabular}{lrrrrrrr}
\hline & $\mathbf{X 4 7 3 7 2 9}$ & $\mathbf{X 4 7 3 7 3 0}$ & $\mathbf{X 4 7 3 7 3 1}$ & $\mathbf{X 8 1 0 5 1 5 0}$ & $\mathbf{X 8 1 0 5 1 5 3}$ & $\mathbf{X 8 1 0 5 1 8 1} \mathbf{X 8 3 0 7 7 5 1}$ \\
$\mathbf{X 4 7 3 7 2 9}$ & & 0.631 & 0.585 & 0.190 & 0.126 & 0.344 & 0.268 \\
$\mathbf{X 4 7 3 7 3 0}$ & 0.631 & & 0.064 & 0.647 & 0.631 & 0.328 & 0.620 \\
$\mathbf{X 4 7 3 7 3 1}$ & 0.585 & 0.064 & & 0.622 & 0.610 & 0.330 & 0.589 \\
$\mathbf{X 8 1 0 5 1 5 0}$ & 0.190 & 0.647 & 0.622 & & 0.176 & 0.369 & 0.127 \\
$\mathbf{X 8 1 0 5 1 5 3}$ & 0.126 & 0.631 & 0.610 & 0.176 & & 0.343 & 0.163 \\
$\mathbf{X 8 1 0 5 1 8 1}$ & 0.344 & 0.328 & 0.330 & 0.369 & 0.343 & & 0.330 \\
$\mathbf{X 8 3 0 7 7 5 1}$ & 0.268 & 0.620 & 0.589 & 0.127 & 0.163 & 0.330 & \\
\hline
\end{tabular}


Table 2. Example metadata available for the seven samples in Fig. 2

\begin{tabular}{|c|c|c|c|c|c|c|}
\hline $\begin{array}{l}\text { Storage } \\
\text { number }\end{array}$ & Sample Type & Lithology & Lithostratigraphy & Base Age & Top Age & Reference \\
\hline 473729 & Rock sample & Sandstone & Lyell Land Group - Sandertop Formation & Tonian & Tonian & Rehnstrøm et al. 2010 \\
\hline 473730 & Rock sample & Sandstone & Kap Kolthoff Group & Givetian & Famennian & Rehnstrøm et al. 2010 \\
\hline 473731 & Rock sample & Sandstone & Kap Kolthoff Group & Givetian & Famennian & Rehnstrøm et al. 2010 \\
\hline 8105150 & Stream sediment sample & - & - & - & - & Rehnstrøm et al. 2010 \\
\hline 8105153 & Stream sediment sample & - & - & - & - & Rehnstrøm et al. 2010 \\
\hline 8105181 & Stream sediment sample & - & - & - & - & Rehnstrøm et al. 2010 \\
\hline 8307751 & Stream sediment sample & - & - & - & - & Rehnstrøm et al. 2010 \\
\hline
\end{tabular}

peak around $1980 \mathrm{Ma}$, which is well known from the tonalitic gneiss that occur in the basement northeast of the area (Kalsbeek et al. 2008).

Samples 8105153, 8105150 and 8307751 (Figs 3D, E, F) represent stream sediments collected from the present-day drainage system on Ymer $\varnothing$. They have very similar detrital zircon age distributions that resemble those of the Upper Proterozoic Eleonore Bay Supergroup bedrock (see sample 473729; Fig 3A). This supports the view that stream sediment offers a good representation of the catchment bedrock geology. Stream sample 8105181 (Fig. 3G) from the mainland has a very complex detrital zircon age distribution suggesting a fundamental difference in the bedrock geology in the catchment area of this sample.

The analytical module allows users to calculate and visualise cumulative age distributions and Kolmogorov-Smirnov dissimilarities (Fig. 4) - a widely used method for comparing mineral age distributions. This is enabled through a plugin between the database and the freely available statistical programming software R (R Development Core Team 2008). These functionalities are part of the 'provenance' package' developed specifically for detrital sediment provenance analysis (Vermeesch et al. 2016). The similarities between e.g. samples 473730 and 473731 are clearly seen in Figures 4A and $4 \mathrm{~B}$, and in Table 1 .

\section{Outlook}

Compiling the large amount of available provenance data into a regional, cross-border, web-database will make these types of data much more accessible and applicable to industry and the research community. In doing so, we hope to promote the use of these data in studies of the North Atlantic region. With an extensive database covering both sides of the Atlantic Ocean more comprehensive source-to-sink analyses can be made, resulting in an improved understanding of onshore-offshore provenance relationships.

In the long-term, we hope to include more data from neighbouring geographic areas such as the Russian and Canadian Arctic, since detrital material in the North Atlantic may have been derived from these areas. It is envisaged that more than 100000 detrital zircon grains from the North Atlantic Region have been dated, and the aim is to capture the majority of these in the database, making them available for data comparison (e.g. with statistical tools) and visualisation to enhance the understanding of the regional reservoir geology. Users are expected to upload their own provenance data in return for using the database.

It is also possible to restrict access to certain data in the database, so that they are kept confidential for a time. This is an important feature for these types of datasets, many of which are funded by private companies and have confidentiality clauses imposed for a finite period. For more information contact the lead-author.

\section{References}

Fleming, E.J., Flowerdew, M.J., Smyth, H.R., Scott, R.A., Morton, A.C., Omma, J.E., Frei, D. \& Whitehouse M. J. 2016: Provenance of Triassic sandstones on the southwest Barents Shelf and the implication for sediment dispersal patterns in the northwest Pangea. Marine and Petroleum Geology 78, 516-535. https://doi.org/10.1016/j.marpetgeo.2016.10.005

Kalsbeek, F., Thrane, K., Higgins, A.K., Jepsen, H.F., Leslie, A.G., Nutman, A.P. \& Frei, R. 2008: Polyorogenic history of the East Greenland Caledonides. In: Higgins et al. (eds): Memoir 202: The Greenland Caledonides: Evolution of the Northeast Margin of Laurentia. Boulder, Colorado: Geological Society of America, 55-72. https://doi. org/10.1130/2008.1202(03)

Kirkland, C.L., Pease, V., Whitehouse, M.J. \& Ineson, J.R. 2009: Provenance record from Mesoproterozoic-Cambrian sediments of Peary Land, North Greenland: implications for the ice-covered Greenland Shield and Laurentian paleogeography. Precambrian Research 170, 43-60. https://doi.org/10.1016/j.precamres.2008.11.006

Lorenz, H., Gee, D.G., Korago, E., Kovaleva, G., McClelland, W.C., Gilotti, J.A. \& Frei, D. 2013: Detrital zircon geochronology of Palaeozoic Novaya Zemlya - a key to understanding the basement of the Barents Shelf. Terra Nova 25, 496-503. https://doi.org/10.1111/ter.12064

Morton A.C., Whitham, A.G. \& Fanning C.M. 2005: Provenance of Late Cretaceous to Palaeocene submarine fan sandstones in the Norwegian Sea: Integration of heavy mineral, mineral chemical and zircon age data. Sedimentary Geology 182, 3-28. https://doi.org/10.1016/j. sedgeo.2005.08.007

Olivarius, M., Bjerager, M., Keulen, N., Knudsen, C. \& Kokfelt, T.F. 2018: Provenance of basinal sandstones in the Upper Jurassic Hareelv Formation, Jameson Land Basin, East Greenland. In: Ineson, J. \& Bojesen- 
Koefoed, J.A. (eds): Petroleum geology of the Upper Jurassic - Lower Cretaceous of East and North-East Greenland: Blokelv-1 borehole, Jameson Land Basin. Geological Survey of Denmark and Greenland Bulletin 42, 39-64.

R Development Core Team 2008. R: A language and environment for statistical computing. R Foundation for Statistical Computing, Vienna, Austria. ISBN 3-900051-07-0, URL http://www.R-project.org.

Rehnström, E.F., Thrane, K., Kokfelt, T.F. \& Frei, D. 2010: Age distribution of detrital zircon grains in sandstones and stream sediments from East Greenland north of $70^{\circ} \mathrm{N}$. Geological Survey of Denmark and Greenland Report 2010/130. 125 pp

Røhr, T. S., Andersen, T. \& Dypvik, H. 2008: Provenance of Lower Cretaceous sediments in the Wandel Sea Basin, North Greenland. Journal of the Geological Society 165, 755-767. https://doi.org/10.1144/001676492007-102

Sláma, J., Walderhaug, O., Fonneland, H., Kosler, J. \& Pedersen, R.B. 2011: Provenance of Neoproterozoic to upper Cretaceous sedimentary rocks, eastern Greenland: Implications for recognizing the sources of sediments in the Norwegian Sea. Sedimentary Geology 238, 254-267. https://doi.org/10.1016/j.sedgeo.2011.04.018
Thomsen, T.B., Heijboer, T., \& Guarnieri, P. 2016: jAgeDisplay: software for evaluation of data distributions in U-Th-Pb geochronology. Geological Survey of Denmark and Greenland Bulletin 35, 103-106.

Vermeesch, P., Resentini, A. \& Garzanti, E. 2016: An R package for statistical provenance analysis. Sedimentary Geology 336, 14-25. https:// doi.org/10.1016/j.sedgeo.2016.01.009

\section{How to cite}

Knudsen, C., Sønderholm, M., Heijboer, T., Kristensen, J.Å. \& Bering, D. 2019: The North Atlantic Provenance Database: an introduction. Geological Survey of Denmark and Greenland Bulletin 43, e2019430301.https://doi.org/10.34194/GEUSB-201943-03-01

${ }^{*}$ Corresponding author: Christian Knudsen |E-mail: ckn@geus.dk

${ }^{1}$ Geological Survey of Denmark and Greenland (GEUS), Øster Voldgade 10, DK-1350, Copenhagen K, Denmark.

${ }^{2}$ Department of Physical Geography and Ecosystem Science, Lund University, Sölvegatan 12, S-223 62 Lund, Sweden.

${ }^{3}$ Norwegian Petroleum Directorate, Professor Olav Hansens vei 10, Postboks 600, 4003 Stavanger, Norway. 